\title{
Fasciíte necrosante: revisão com enfoque nos aspectos dermatológicos*
}

\section{Necrotizing Fasciitis: new insights with a focus on dermatological aspects*}

\author{
Izelda Maria Carvalho Costa \\ Simone Saraiva de Pontes ${ }^{2}$
}

Andrea Leão Santos Veiga Cabral ${ }^{2}$

\author{
Janaina Figueiredo de Amorim ${ }^{2}$
}

\begin{abstract}
Resumo: Fasciíte necrosante é infecção bacteriana destrutiva e rapidamente progressiva do tecido subcutâneo e fáscia superficial, associada a altos índices de morbimortalidade, se não tiver tratamento precoce. Recentemente, inúmeros casos publicados têm demonstrado aumento na freqüência e gravidade dessa infecção, particularmente causada pelo Streptococcus do grupo A (GAS) e que acomete até mesmo pessoas jovens e saudáveis. Classifica-se em tipo I, quando causada por flora mista de anaeróbios e outras bactérias, e tipo II, quando causada pelo GAS isolado ou associado ao Staphylococcus aureus. Os fatores predisponentes incluem: doenças crônicas e malignas, abuso de álcool, uso de drogas endovenosas, lesões da pele como varicela, úlceras crônicas, psoríase, cirurgia, traumas abertos e fechados, entre outros. Clinicamente destacam-se: a dor intensa, o edema grave, a rápida progressão e a resposta pobre à antibioticoterapia. É necessário um alto índice de suspeição para o diagnóstico clínico, que é confirmado à intervenção cirúrgica, com a evidência de necrose da fáscia superficial. Os exames radiológicos são úteis, e o diagnóstico diferencial deve ser feito principalmente com celulite em seu estágio inicial. O tratamento, que deve ser precoce, é feito com antibióticos de amplo espectro, debridamento cirúrgico agressivo e medidas de suporte clínico e nutricional.

Palavras-chave: fasciíte necrosante; fascíte necrosante/diagnóstico; fasciíte necrosante/terapia.
\end{abstract}

\begin{abstract}
Summary: Necrotizing fasciitis is a destructive and quickly progressing bacterial infection of the subcutaneous layer and superficial fascia. It is associated with high levels of unbealthiness and mortality if not treated early. Recently, countless published cases demonstrated an increasing frequency and severity of these infections, especially those caused by Group A Streptococcus (GAS), which afflicts even young and bealthy persons. It is classified as type I when caused by a mixed anaerobic flora and other bacteria, and type II when caused by GAS alone or in association with Staphylococcus aureus. Predisposing factors include: chronic and malignant diseases, alcohol abuse, intravenous drug use, skin lesions such as chicken pox, chronic ulcers, psoriasis, surgery, and opened or closed traumas, among others. Clinical features are intense pain, severe edema, fast progress and poor antibiotic therapy feedback. A bigh level of suspicion is necessary to achieve a clinical diagnosis for this disease. Moreover, it is confirmed primarily when surgery takes place and reveals the superficial fascia necrosis. Radiological examinations are useful and the differential diagnosis must be done mainly with cellulitis at its initial stage. Treatment must be done early and with broad spectrum antibiotics, aggressive surgical debridement and clinical and nutritional support measures.

Key-words: fasciitis, necrotizing; fasciitis, necrotizing/diagnosis; fasciitis, necrotizing/therapy.
\end{abstract}

\footnotetext{
Recebido em 29.04.2002. / Received in April, $29^{\text {th }}$ of 2002.

Aprovado pelo Conselho Consultivo e aceito para publicação em 18.03.2003. / Approved by the Consultive Council and accepted for publication in March, $18^{\text {th }}$ of 2003. * Trabalho realizado no Hospital Universitário de Brasília. / Work done at "Hospital Universitário de Brasília".

Mestre em Dermatologia, UFMG, Doutor em Dermatologia, UNIFESP. Dermatologista, Hospital Universitário - UnB e Professora Orientadora do curso de pós-graduação em Ciências da Saúde da Universidade de Brasília (UNB). / Master's Degree in Dermatology, UFMG, Ph.D. in Dermatology, UNIFESP. Dermatologist, Hospital Universitário - UnB and Professor, Research Supervisor, University of Brasilia Post-Graduate program in Health Sciences (UNB).

Ex-residentes do Serviço de Dermatologia do Hospital Universitário - UnB. / Ex-resident at the "Serviço de Dermatologia do Hospital Universitário - UnB".

C2004 by Anais Brasileiros de Dermatologia
} 


\section{INTRODUÇÃO}

Fasciíte necrosante (FN) é infecção bacteriana destrutiva e rapidamente progressiva do tecido subcutâneo e fáscia superficial, associada a altos índices de morbimortalidade. $^{1,2}$

A FN também tem sido referida como gangrena estreptocócica hemolítica, úlcera de Meleney, gangrena dérmica aguda, gangrena hospitalar, fasciíte supurativa e celulite necrosante sinergística.

A gangrena de Fournier é a forma de FN que atinge bolsas escrotais e região perineal.

Em seu estágio inicial, a FN pode apresentar-se como uma infecção mais superficial de partes moles, como celulite ou erisipela, e com outras semelhanças quanto à etiologia e aos fatores predisponentes. E devido à alta freqüência, à relativa facilidade no diagnóstico e à boa resposta ao tratamento dessas infecções mais superficiais, pode-se incorrer em falhas terapêuticas nos casos que evoluem com comprometimento da fáscia superficial e tecido subcutâneo, com elevado potencial para complicações graves.

Desse modo, torna-se imprescindível um alto índice de suspeição clínica para realização precoce do diagnóstico e tratamento da FN, reduzindo-se as taxas de morbimortalidade.

A observação clínica no serviço em que atuam os autores e os diversos relatos na literatura mundial, mostrando aumento de freqüência e severidade das infecções de partes moles, principalmente em indivíduos imunossuprimidos, seja por uma doença de base ou outras condições, mas também ocorrendo em indivíduos saudáveis, levou-os a realizar uma extensa revisão da literatura acerca do tema, destacando os aspectos de maior interesse para o dermatologista.

\section{HISTÓRICO}

A síndrome clínica conhecida atualmente como FN, descrita no final do século XVIII, era tida como uma das mais terríveis e fatais doenças que acometiam os militares.

Durante o século XIX, a patologia ficou conhecida como úlcera maligna, fagedênica e, eventualmente, gangrena hospitalar.

Nos EUA, os primeiros casos de gangrena hospitalar foram descritos durante a Guerra Civil Americana. Na época, o único tratamento disponível era a amputação da extremidade acometida, procedimento esse associado ao índice de mortalidade global de $45 \%$.

Em 1924, Meleney descreveu uma doença ulcerosa, progressiva, chamada "gangrena estreptocócica hemolítica aguda", intensamente dolorosa, produzida por uma associação sinergística de estreptococos e estafilococos. Essa entidade apresentava mortalidade em torno de $20 \%$ e foi finalmente denominada "fasciíte necrosante". ${ }^{2}$

O Streptococcus do grupo A (GAS) é um dos patógenos que significativamente influenciaram a história do homem. A epidemia de escarlatina, com mortalidade superior a $30 \% \mathrm{em}$ crianças, marcou a história da medicina. As infecções de feri-

\section{INTRODUCTION}

Necrotizing fasciitis (NF) is a destructive and quickly progressing bacterial infection of the subcutaneous tissue and superficial fascia, associated with high levels of morbidity and mortality. ${ }^{1,2}$

NF has also been referred to as hemolytic streptococcal gangrene, Meleney's ulcer, acute dermal gangrene, hospital gangrene, suppurative fasciitis and necrotizing synergistic cellulitis.

Fournier's gangrene is a form of NF afflicting the scrotal sac and perineal region. In its initial stage, NF may present with a more superficial infection of the soft skin, such as cellulitis and erysipela, and with other similarities regarding etiology and predisposing factors. Due to its high frequency, relative diagnostic ease and good response to treatment in these more superficial infections, therapeutic failures may be brought on in cases where there is progression with superficial fascia and subcutaneous affection with a high potential for severe complications.

As such, a high index of clinical suspicion is indispensable for early diagnosis and treatment of NF, which may reduce morbidity and mortality rates.

Clinical observation at the Service where the authors work and diverse reports found in the international literature show an increasing frequency and severity of soft tissue infections, mainly in immunosuppressive individuals. This is the case either for a basic disease or for other conditions, but also for those afflicting otherwise healthy individuals. It is also what has led the authors of the present paper to the carry out an extensive review of the literature on this theme so as to highlight the most interesting aspects as far as the dermatologist is concerned.

\section{HISTORY}

The clinical syndrome currently known as NF was first described at the end of the 18th century. It was one of the most terrible and fatal diseases to afflict soldiers.

In the 19th century, the pathology was known as malignant ulcer, phagedena and, eventually, hospital gangrene.

In the USA, the first cases of hospital gangrene were described during the Civil War. At the time, the only treatment available was amputation of the afflicted extremity. This procedure had a global mortality rate of $45 \%$.

In 1924, Meleney described an ulcerous, progressive disease called "acute hemolytic streptococcal gangrene", which was intensely painful and produced by a synergistic association of streptococcus and staphylococcus. This entity presented a roughly $20 \%$ mortality rate and was finally called "necrotizing fasciitis". 2

Group A streptococcus (GAS) is one of the pathogens to have significantly influenced the history of mankind. The scarlet fever epidemic, with a mortality rate of over $30 \%$ in children, marked the history of medicine. Wound infections by GAS, in either soldiers or civilians, 
da pelo GAS, em militares e civis, e a sepse puerperal eram as mais temidas infecções no período anterior aos antibióticos. ${ }^{4}$

No século XX, a proporção de infecções severas causadas pelo Streptococcus do grupo A apresentou marcante declínio. Isso pode ser facilmente atribuído à melhoria das condições de vida e, mais tarde, ao desenvolvimento dos antibióticos, embora, paralelamente, a virulência do agente pareça ter diminuído. ${ }^{4}$

\section{ETIOLOGIA}

O Streptococcus hemolítico do grupo A e o Staphylococcus aureus, isoladamente ou em sinergismo, são com freqüência os agentes iniciadores da FN.

Já não é tão comum quanto antes a FN causada por Clostridium perfringens, que, num estudo de 1990, só foi isolado em percentual que variou de 5 a $15 \%$ dos pacientes. $^{5}$

No entanto, outros patógenos aeróbios e anaeróbios podem estar presentes, incluindo Bacteroides, Clostridium, Peptostreptococcus, Enterobacteriaceae, coliformes, Proteus, Pseudomonas e Klebsiella. O Bacteroides fragilis é geralmente encontrado fazendo parte da flora mista, em combinação com Escherichia coli. Eles não causam a infecção diretamente, mas podem contribuir na redução da produção de interferon e da capacidade fagocitária de macrófagos e polimorfonucleares.

\section{INCIDÊNCIA}

Na década de 1980 e início dos anos 90, uma grande quantidade de artigos na literatura médica sugeria que se estava diante do ressurgimento das infecções severas por Streptococcus do grupo A. Ao que parece, houve exagero e sensacionalismo, tendo surgido a denominação de bactérias comedoras de carne (flesh-eating bacteria). ${ }^{3}$ Tais infecções não são descritas de maneira uniforme, e, portanto, as estatísticas estão longe de ser definitivas, sendo os relatos muitas vezes anedóticos.

Há ainda autores que especulam a possível emergência de uma nova síndrome clínica em adultos, fasciíte necrosante causada pelo Streptococcus do grupo B, que teria, recentemente, adquirido aumento na habilidade para causar tal infecção. ${ }^{5}$

De fato, a maioria dos autores são cuidadosas e referem um "aparente" aumento dessas infecções. ${ }^{4} \mathrm{O}$ relato mais convincente do aumento das infecções graves pelo GAS é de Martin e Hoiby, na Noruega em 1987 e 1988, incluindo casos de bacteremia, freqüentemente severos, com mortalidade de $25 \%$, acometendo pessoas jovens e saudáveis. ${ }^{6}$

Kaul e colaboradores realizaram um estudo prospectivo em Ontário, entre 1991 e 1995, de 77 casos de fasciíte necrosante estreptocócica. A incidência aumentou de 0,085 por 100.000 habitantes no primeiro ano do estudo para 0,40 por 100.000 no último. ${ }^{2} \mathrm{O}$ CDC estima que ocorram entre 500 e 1.500 casos de fasciíte necrosante nos EUA a cada ano. ${ }^{7}$ and puerperal sepsis were the most dreaded infections in the age before antibiotics. ${ }^{4}$

In the 20th century, the proportion of severe infections caused by Group A Streptococcus showed a sharp decline. This may be easily attributed to improved living conditions and, later, to the development of antibiotics. However, the virulence of the agent seems to have diminished independently. ${ }^{4}$

\section{ETIOLOGY}

Group A hemolytic streptococcus and staphylococcus aureus, alone or in synergy, are increasingly the initiating agents of $N F$.

They are surely not as common as the earlier form of $N F$ caused by Clostridium perfringens. In a study dating from 1990, this latter agent was still only isolated in a percentage varying from 5 to $15 \%$ of patients.

Nonetheless, other aerobic and anaerobic pathogens may be present, including Bacteroides, Clostridium, Peptostreptococcus, Enterobacteriaceae, coliforms, Proteus, Pseudomonas and Klebsiella. Bacteroides fragilis is usually found as part of a mixed flora in combination with Escherichia coli. They do not directly cause the infection, but may contribute to reducing interferon production and the phagocyte capacity of macrophages and polymorphonuclei.

\section{INCIDENCE}

In the 1980s and beginning of the 1990s, a large number of articles in the medical literature suggested that there was a resurgence of severe Group $A$ Streptococcus infections. As far as what can be determined, it seems that this was exaggerated and sensationalistic, which contributed to coining the term "flesh-eating bacteria". ${ }^{3}$ Such infections are not uniformly described. The statistics are far from being definitive, with reports often being anecdotal.

Some authors still speculate about the possible emergence of a new clinical syndrome in adults, namely necrotizing fasciitis resulting from Group B Streptococcus. They suggested that the latter would have recently acquired an increasing ability to cause such infections. ${ }^{5}$

In fact, most authors are careful and refer to an "apparent" increase of these infections. ${ }^{4}$ The most convincing report on the increasingly severe infections by GAS was drafted by Martin and Hoiby from Norway in 1987 and 1988. Their report includes often severe cases of bacteremia with a $25 \%$ mortality rate, which affects young and healthy persons. ${ }^{6}$

Kaul and collaborators carried out a prospective study of 77 cases of streptococcus necrotizing fasciitis in Ontario between 1991 and 1995. The incidence increased from 0.085 per 100,000 inhabitants in the first year of the study to 0.40 per 100,000 by the second. ${ }^{2}$ The CDC estimates that 500 to 1,500 cases of necrotizing fasciitis occur in the USA yearly. ${ }^{7}$ 


\section{CLASSIFICAÇÃO}

A FN é classificada em tipo I e tipo II (Quadro).

A do tipo I ou celulite necrosante é caracterizada pelo isolamento de pelo menos uma espécie de anaeróbio obrigatório, como o Bacterioides e Peptostreptococcus, em combinação com um ou mais organismos anaeróbios facultativos, como o Enterobacter e os estreptococos não pertencentes ao grupo $\mathrm{A} .{ }^{3} \mathrm{O}$ tipo I é mais comum após cirurgias e em pacientes com diabetes e doença vascular periférica. ${ }^{1}$

O tipo II ou gangrena estreptocócica é caracterizado pelo isolamento do Streptococcus do grupo A isolado ou associado ao Staphylococcus aureus. Ocorre tipicamente após ferimentos penetrantes, procedimentos cirúrgicos, queimaduras e traumas, os mínimos incluídos. No entanto, a história de trauma prévio pode não estar presente em todos os casos. ${ }^{1}$

\section{FISIOPATOLOGIA}

Vários componentes da superfície do Streptococcus pyogenes estão envolvidos em sua capacidade de aderência e invasão, como a proteína $\mathrm{M}$ e a capsular. A estreptolisina $\mathrm{O}$ e outros produtos bacterianos, como as exotoxinas pirogênicas, estão envolvidos na injúria tecidual e necrose. As toxinas $\mathrm{A}$ e $\mathrm{C}$ agem como superantígenos e são expressadas por cepas associadas à síndrome do choque tóxico.

Em relação ao Staphylococcus aureus, os principais fatores patogênicos são a cápsula, a proteína $\mathrm{A}$ e a toxina da síndrome do choque tóxico estafilocócico.

Na FN, como na síndrome do choque tóxico estreptocócico (STSS), ocorrem reações de superantígenos com ativação de mais de $10 \%$ de linfócitos CD4+ e liberação de grande quantidade de citocinas.

Produtos estreptocócicos conhecidos como gatilhos das reações de superantígenos são as exotoxinas pirogênicas, spe A, spe B e spe C e proteína-M. ${ }^{8}$ Superantígenos

\section{CLASSIFICATION}

NF is classified into types I and II (Chart). Type I or necrotizing cellulitis is characterized by isolation of at least one species of an obligatory anaerobic, such as Bacterioides and Peptostreptococcus, in combination with one or more optional anaerobic organism(s), like Enterobacter and streptococci not belonging to Group A. ${ }^{3}$ Type I most commonly occurs following surgery and in patients with diabetes and peripheral vascular disease. ${ }^{l}$

Type II or streptococcus gangrene is characterized by the isolation of Group A Streptococcus, either alone or in association with Staphylococcus aureus. It typically occurs after penetrating injuries, surgical procedures, burns and traumas, including even the mildest varieties. However, the previous trauma history may not be present in all cases. ${ }^{l}$

\section{PHYSIOPATHOLOGY}

Various superficial components of Streptococcus pyogenes are involved in their ability to adhere and invade, such as M-protein and capsular protein. Streptococcal $O$ and other bacterial products, such as pyrogenic exotoxins, are involved in tissue damage and necrosis. Toxins $A$ and $C$ act like superantigens and are expressed by cepas in association with toxic shock syndrome.

Regarding Staphylococcus aureus, the main pathogenic factors are the capsule, A protein and the toxin from staphylococcal toxic shock syndrome.

In NF, as well as in streptococcal toxic shock syndrome (STSS), superantigen reactions occur with the activation of over 10\% CD4+ lymphocytes and the release of a large amount of cytokines.

Streptococcal products known as superantigen reaction triggers are the pyrogenic exotoxins, SPE A, SPE B and $S P E C$ and M-protein. ${ }^{8}$ Superantigens like pyrogenic exo-

Quadro: Tipos de Fasciíte Necrosante / Chart: Types of Necrotizing Fasciitis

\begin{tabular}{|lll|}
\hline Quadro Clínico / Clinical Picture & FN Tipo I / NF Type I & FN Tipo II / NF Type II \\
Dor / Pain & presente / present & presente / present \\
Gás Tecidual / Tissue Gas & presente / present & ausente / absent \\
Odor do Exsudato / Odor of the Exudate & forte / strong & fraco / weak \\
Alterações Cutâneas / Cutaneous Changes & eritema, áreas necróticas, anestesia => & fáscia necrótica \\
& erythema, necrotic areas, anesthesia $=>$ necrotizing fasciitis \\
Alterações Sistêmicas / Systemic Changes & proeminentes / prominent & proeminentes / prominent \\
Progressão / Progression & rápida / fast & rápida / fast \\
Fatores Predisponentes / Predisposing Factors & após cirurgia abdominal & espontânea / traumas mínimos \\
& ou perineal & spontaneous / minimal traumas \\
& following abdominal or & perineal surgery
\end{tabular}


como a exotoxina pirogênica A interagem com monócitos e linfócitos $\mathrm{T}$, resultando em proliferação de células $\mathrm{T}$, produção de monocinas (TNF $\alpha$, interleucina 1, interleucina 6) e linfocinas (TNF $\beta$, interleucina 2 e interferon- $\gamma$ ). ${ }^{9}$

\section{FATORES PREDISPONENTES}

Os fatores predisponentes incluem as seguintes condições: doenças crônicas (doenças cardíacas, doença vascular periférica, doenças pulmonares, insuficiência renal e diabetes mellitus), abuso de álcool, condições imunossupressoras (uso de corticosteróides sistêmicos, doenças do colágeno, infecção pelo HIV, transplantes de órgãos sólidos e doenças malignas em tratamento), uso de drogas endovenosas, cirurgias, varicela em crianças, úlceras isquêmicas e de decúbito, psoríase, contato com pessoas infectadas por Streptococcus e traumas cutâneos penetrantes e fechados ou até mínimos. ${ }^{2,10-14}$

Kaul R, em sua análise de 77 casos, encontrou em $71 \%$ deles pelo menos uma doença crônica de base associada. ${ }^{2}$ Bilton e colaboradores, em estudo de 68 casos encontrou dados semelhantes $(73 \%) .^{16}$

Mais recentemente, muitos casos relatados na literatura sugerem a associação de FN com uso de antiinflamatórios não esteroidais. Entre as hipóteses estão a indução de depressão da função linfocitária, como também a linfopenia, contribuindo para sépsis em pacientes que sofreram apenas pequenos traumas. ${ }^{16}$ Outra hipótese é o simples mascaramento dos sinais e sintomas de uma infecção preexistente, contribuindo para o retardo do diagnóstico.

Alguns autores especulam que em certas infecções de pele e tecido celular subcutâneo, particularmente aquelas causadas por Streptococcus $\beta$-hemolíticos do grupo A, esse retardo no diagnóstico pode permitir que uma infecção simples possa progredir para FN. ${ }^{17}$

Guibal e colaboradores utilizaram um modelo animal de fasciíte necrosante estreptocócica para estudar os efeitos da administração parenteral de antiinflamatórios não esteroidais na evolução da infecção. Os resultados sugerem que o aumento da severidade dessas infecções, relacionado ao uso de antiinflamatórios, seja causado pela demora no diagnóstico e tratamento, devido ao fato de seus efeitos clínicos levarem a uma aparente melhora do quadro, e não por diminuição das defesas. ${ }^{19}$

Até o momento, a relação causal entre fasciíte necrosante e antiinflamatórios não esteroidais ainda não pode ser estabelecida.

\section{CARACTERÍSTICAS CLÍNICAS}

A FN inicia como área eritematosa, dolorosa e localizada, que aumenta em horas ou dias, associada a edema tecidual importante. Em seguida, ocorre cianose local e formação de bolhas de conteúdo amarelado ou avermelhadoescuro. A área envolvida torna-se rapidamente demarcada, circundada por borda eritematosa e recoberta por tecido necrótico. Nesse momento, desenvolve-se anestesia da pele que recobre a lesão devido à destruição do tecido subcutâ- toxin A interact with monocytes and T-lymphocytes, resulting in the proliferation of T cells, production of monokines (TNF-alpha, interleukin 1, interleukin 6) and lymphokines (TNF $\beta$, interleukin 2 and interferon-gamma). ${ }^{9}$

\section{PREDISPOSING FACTORS}

Predisposing factors include the following conditions: chronic diseases (cardiac diseases, peripheral vascular disease, pulmonary diseases, renal insufficiency and diabetes mellitus), alcohol abuse, immunosuppressive conditions (use of systemic corticosteroids, collagen diseases, $H I V$ infection, solid organ transplants and malignant diseases in treatment), the use of endovenous drugs, surgeries, chicken pox in children, ischemic and decubitus ulcers, psoriasis, contact with persons infected with Streptococcus and with penetrating, closed or even minimal cutaneous traumas. $^{2,10-14}$

In $71 \%$ of the 77 cases he analyzed, Kaul R found at least one basic associated chronic disease. ${ }^{2}$ In a study of 68 cases, Bilton and collaborators found similar data (73\%). ${ }^{16}$

More recently, many cases reported in the literature suggest an association of NF with the use of nonsteroidal anti-inflammatories. Among the hypotheses one may find induced depression of the lymphocyte function as well as lymphopenia contributing to sepsis in patients suffering from only small traumas. ${ }^{16}$ Another hypothesis is the simple masking of signs and symptoms of a pre-existing infection, which contributes to delaying the diagnosis.

Some authors speculate that in certain skin and subcutaneous cellular tissue infections, especially those caused by Group A $\beta$-Hemolytic Streptococcus, this delay in diagnosis may allow a simple infection to progress into $\mathrm{NF}^{17}$

Guibal and collaborators utilize an animal model of streptococcal necrotizing fasciitis to study the effects of parenteral administration of nonsteroidal anti-inflammatories on the progression of the infection. The results suggest that the increasing severity of these infections, related to the use of anti-inflammatories, would be caused by a delay in diagnosis and treatment. This is due to the fact that its clinical effects lead to an apparent improvement of the condition, and not to reducing defenses. ${ }^{19}$

Up until the present time, the causal relation between necrotizing fasciitis and nonsteroidal anti-inflammatories cannot yet be established.

\section{CLINICAL CHARACTERISTICS}

$N F$ begins as an erythematous, sore and localized area, increasing hourly and daily and occurring in association with significant tissue edema. Local cyanosis and yellow or dark-reddish content blister formations occur thereafter. The area involved quickly becomes demarcated and circled by an erythematous border and covered over by necrotic tissue. At this time, anesthesia of the skin covering over the lesion develops. This is due to the destruction of the 


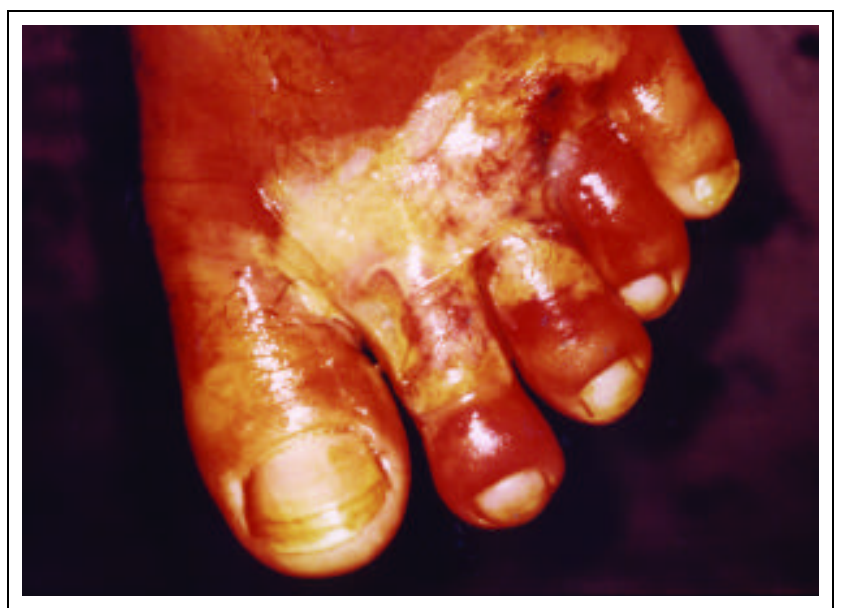

Figura 1: Paciente de 55 anos, de cor parda, portador de DM tipo 2, com edema e eritema no dorso do pé esquerdo, áreas de ulceração e necrose interdigital (FN tipo I) / Figure 1: A 55 year-old, pardo patient, a DM type 2 carrier, with edema and erythema on the dorsal aspect of the left foot, ulcerated areas and interdigital necrosis (NF type 1)

neo subjacente e trombose dos vasos nutrientes, causando necrose das fibras nervosas.

A pele é inicialmente poupada, mas, com a extensão do processo necrótico, torna-se comprometida (Figuras 1, 2 e 3).

Comumente, o edema pode ser observado antes de outros sinais cutâneos aparecerem. A dor muito intensa e desproporcional, mesmo após o início do tratamento é um indício importante de FN.'

A necrose da fáscia é tipicamente mais extensa do que sugere o aspecto clínico. Com o acometimento de planos mais profundos, pode ocorrer formação de crostas necróticas extensas.

Sem tratamento, é possível haver envolvimento secundário da camada muscular, resultando em miosite ou mionecrose. celulite. ${ }^{3}$

$\mathrm{Na}$ fase inicial, pode ser difícil distinguir entre FN e

Quanto ao sítio primário mais comum da infecção, os membros inferiores representam cerca de $50 \%$ dos

Figura 3: Paciente de 30 anos, de cor parda, do sexo feminino, portadora de linfoma e Aids com úlcera extensa, algumas áreas de necrose e com exposição de tendões no dorso do pé direito (FN tipo II)

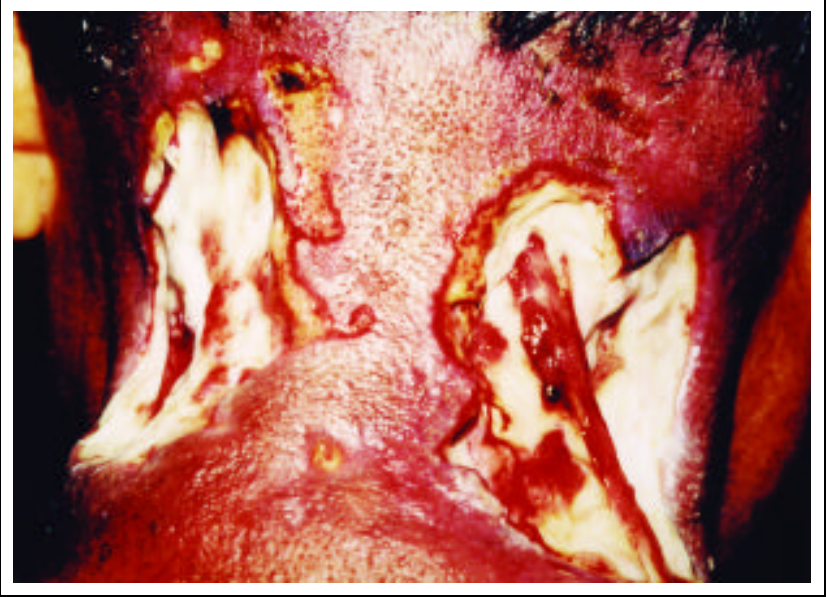

Figura 2: Paciente de 62 anos, de cor parda, do sexo masculino, portador de DM tipo 2, portador de duas lesões úlceronecróticas na região cervical com exposição de tendões (FN tipo I) / Figure 2: A 62-year-old male, pardo patient, DM type 2 carrier, having two ulceronecrotic lesions on the cervical region with tendons exposed (NF type 1)

underlying subcutaneous tissue and thrombosis of the nutrient vessels, which causes necrosis of the nervous fibers.

The skin is initially spared. But with the extension of the necrotic process, the skin also becomes afflicted (Figures 1, 2 and 3).

Edema may be commonly observed prior to the appearance of other cutaneous signs. The very intense and disproportional pain is an important indication of $N F$, even after treatment begins. ${ }^{1}$

Necrosis of the fascia is typically more extensive than what the clinical aspect suggests. With affliction of the deepest tissue layers, extensive necrosis crust formation may occur.

If not treated, it is possible to have secondary involvement of the muscular layer, resulting in myositis or myonecrosis.

In the initial phase, it is difficult to distinguish NF from cellulitis. ${ }^{3}$

As for the most common primary infection site, the lower limbs represent roughly $50 \%$ of cases, followed by the

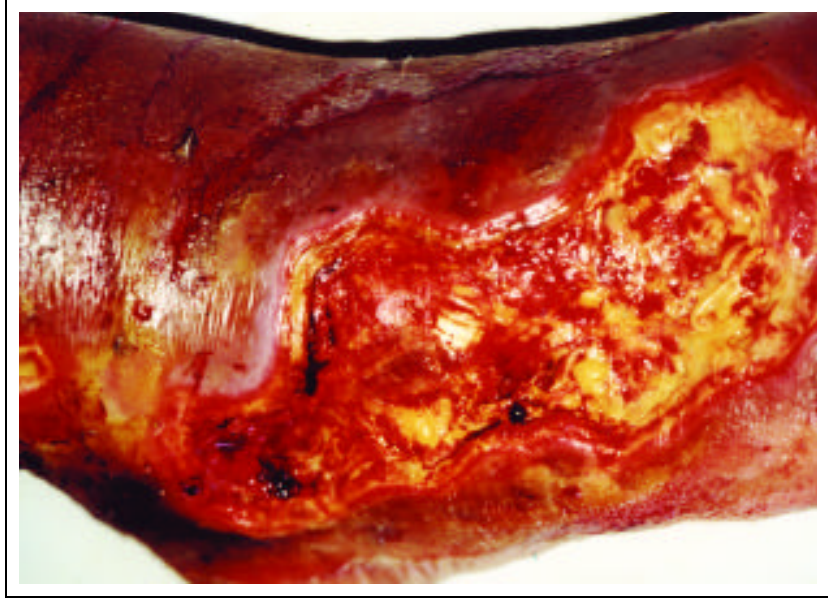

Figure 3: A 30-year-old female parda patient, $a$ lymphoma carrier with AIDS, an extensive ulcer some necrosis areas and tendon exposure on the dorsal aspect of the right foot (NF type II) 
casos, seguidos por membros superiores (29\%), tronco (9\%), região perineal $(8 \%)$ e face $(1 \%){ }^{2}$

Apesar de a FN poder acometer pacientes de qualquer idade, há um aumento significativo da incidência em idosos (acima dos 65 anos), como em pacientes com pelo menos uma doença de base. No entanto, vários relatos na literatura enfatizam a ocorrência de infecções estreptocócicas graves e FN em adultos jovens, previamente sadios. , $^{19,20,21}$ $\mathrm{O}$ acometimento de crianças é menos freqüente, e cerca da metade dos casos ocorre em pacientes com varicela.

Não há predileção quanto ao sexo.

\section{HISTOPATOLOGIA}

A histopatologia da FN demonstra necrose da fáscia superficial, infiltrado de polimorfonucleares e edema da derme reticular, gordura subcutânea e fáscia superficial. ${ }^{1,2}$ Majeski realizou biópsia de congelação numa série de 43 pacientes que apresentavam processo inflamatório. Em 20 deles foi comprovada fasciíte necrosante, sendo rápida e adequadamente tratada, sem que houvesse óbito. Nenhum caso de gangrena infecciosa ocorreu no grupo em que a biópsia não demonstrou evidências de FN. O autor conclui que a biópsia é um método complementar útil no estabelecimento precoce e preciso do diagnóstico dessas infecções. ${ }^{23}$

A biópsia de congelação, realizada antes da intervenção cirúrgica, pode ser bastante útil para o diagnóstico, revelando um infiltrado maciço de polimorfonucleares com necrose focal e formação de microabscessos na fáscia e no tecido subcutâneo (Figura 5). ${ }^{3}$

Outros autores, no entanto, consideram mais importantes a evolução rápida, a severidade da infecção e o isolamento do Streptococcus do grupo A do que os achados histopatológicos de uma área necrótica. ${ }^{24}$

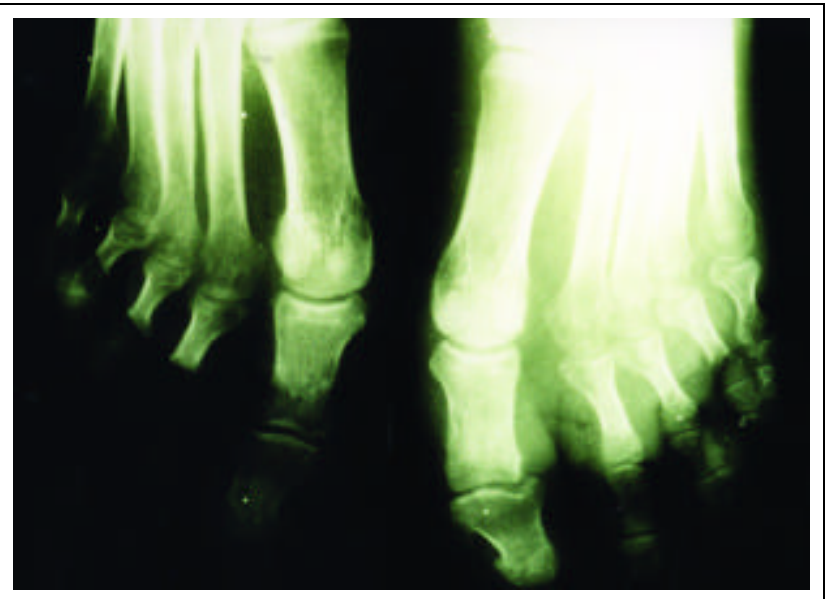

Figura 4: Paciente de 55 anos, de cor parda, portador de DM tipo 2 e FN tipo I, ao exame radiológico apresentando gás subcutâneo no segundo pododáctilo esquerdo / Figure 4: A 55-year-old pardo patient, DM type 2 and NF type 1 carrier, with the radiological test showing subcutaneous gas in the second left toe. upper limbs (29\%), trunk (9\%), perienal region (8\%) and face $(1 \%)^{2}$

Despite the fact that $N F$ affects patients of any age group, there is a significant increase of incidence among the elderly (over 65 years of age), and with patients having at least one basic illness. However, various reports in the literature emphasize the occurrence of severe streptococcal infections and NF among previously healthy young adults. The affliction of children is less frequent, with roughly half of the cases occurring in patients with chicken pox.

There is no predilection with respect to sex.

\section{HISTOPATHOLOGY}

The histopathology of NF demonstrates superficial necrosis of the fascia, polymorphonuclear infiltrate and reticular edema of the dermis, subcutaneous fat and superficial edema. ${ }^{1,2}$ Majeski carried out a freeze biopsy on a series of 43 patients who showed an inflammatory process. In 20 of them necrotizing fasciitis was confirmed. It was quickly and adequately treated without any deaths occurring. There was no case of infectious gangrene in the group in which the biopsy failed to reveal any evidence of NF. The author concluded the biopsy to be a complementary and useful method to establish the diagnosis of these infections in an early and precise way. ${ }^{23}$

The freeze biopsy, carried out prior to surgery, may be very useful for the diagnosis. It may reveal a soft infiltrate of polymorphonuclears with focal necrosis and formation of microabscesses on the fascia and subcutaneous tissue (Figure 5). ${ }^{3}$

By contrast, other authors consider quick progression, severity of the infection and isolation of Group $A$ Streptococcus to be more important than the histopathologic findings of a necrotic area. ${ }^{24}$

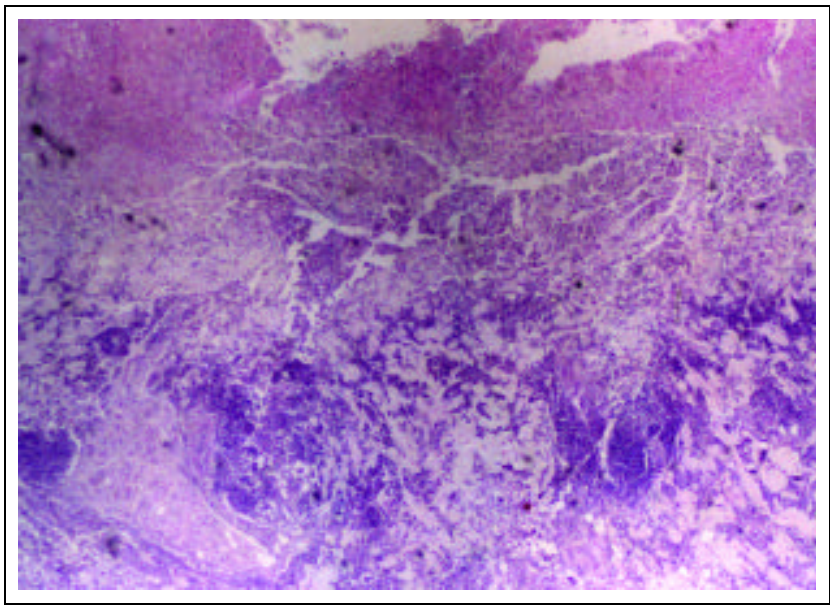

Figura 5: Exame histopatológico

(H.E. 4A) mostrando área ulcerada, supurada.

Figure 5: Histopatbologic exam (H.E. 4A) showing an ulcerated and suppurating area. 


\section{EXAMES RADIOLÓGICOS}

Antes do surgimento da tomografia computadorizada (TC), a radiografia simples era utilizada para confirmar a presença de gás no subcutâneo como evidência de FN (Figura 4). Contudo, a menos que o gás estivesse confinado mais superficialmente, ele era raramente demonstrado por este exame.

Em contraste, a TC proporciona excelente visualização da presença e extensão do gás anormal, além de evidenciar necrose com espessamento assimétrico da fáscia.

Walshaw e Deans revisaram as tomografias de 20 pacientes com FN, e 11 (55\%) deles apresentavam gás no subcutâneo. Os autores sugerem que os nove pacientes que não apresentavam gás no subcutâneo à TC representavam casos de infecção por microorganismos não produtores de gás ou casos em que o tratamento precoce preveniu o acúmulo de gás suficiente para visualização. ${ }^{25}$

Cabe lembrar que a presença de gás não necessariamente indica infecção por Clostridium, uma vez que Escherichia coli, Peptostreptococcus e Bacteroides podem produzir gás em condições apropriadas.

A TC também ajuda no diagnóstico diferencial pela evidência de comprometimento muscular que sugerem mionecrose e outras condições que não a FN, em que tal envolvimento é tardio e secundário. ${ }^{1}$

A ressonância magnética (RM), pela ausência da acentuação do contraste gadolineum em imagens T1, pode proporcionar o diagnóstico precoce da FN, demonstrar a necessidade de cirurgia e determinar a extensão do envolvimento, facilitando assim o plano operatório. ${ }^{26}$ É uma boa técnica para revelar a profundidade da infecção e a presença de necrose.

Infecções de partes moles, incluindo celulites, miosites e fasciítes, são mais bem avaliadas pela TC e RM devido à excelente resolução anatômica e ao contraste dos tecidos. $^{27}$

\section{DIAGNÓSTICO E DIAGNÓSTICO DIFERENCIAL}

Nos estágios iniciais a FN e a celulite são dificilmente distinguíveis. Vários estudos indicam que a FN, freqüentemente, começa com celulite e bolhas. Além disso, a FN e a celulite bolho-hemorrágica apresentam muitos outros fatores em comum. Ambas são condições dolorosas, com potencial de evoluir rapidamente para necrose e gangrena, possuem os mesmos fatores predisponentes e podem ter os mesmos agentes etiológicos (Streptococcus pyogenes). Como na FN, as hemoculturas na celulite bolho-hemorrágica são positivas em mais de $60 \%$ dos casos. Em contraste, são invariavelmente negativas em celulites típicas. ${ }^{?}$

Indícios para o diagnóstico da FN incluem edema inelástico, cianose, palidez e hipoestesia cutâneas, crepitação, fraqueza muscular, odor fétido de exsudatos, ausência de linfangite, rápida progressão da infecção e falta de resposta à antibioticoterapia convencional.

Manifestações sistêmicas de sepse estão usualmente presentes, incluindo alteração do estado mental, taquicar-

\section{RADIOLOGICAL EXAMINATIONS}

Prior to the emergence of computerized tomography (CT), simple X-rays were utilized to confirm the presence of gas in the subcutaneum as evidence of NF (Figure 4). Nevertheless, as the gas was confined more superficially, it was rarely demonstrated by this test.

By contrast, CT provides excellent visualization of the presence and extension of abnormal gaz, in addition to evidencing necrosis with asymmetrical thickening of the fascia.

Walshaw and Deans revised the tomographies of 20 NF patients, and 11 (55\%) of them showed subcutaneous gas. The authors suggest that the nine patients who did not show subcutaneous gas by CT represent cases of infection by microorganisms that are not productive of gas. Or these are cases in which early treatment prevents an accumulation of enough gas to be visualized..$^{25}$

It is useful to recall that the presence of gas does not necessarily indicate infection by Clostridium, given that Escherichia coli, Peptostreptococcus and Bacteroides may produce gas under appropriate conditions.

CT may also help in the diagnostic differential for evidence of muscular involvement that suggests myonecrosis and other non NF conditions in which such involvement is late-onset or secondary. ${ }^{\prime}$

Magnetic resonance (MR), by the lack of accentuation of the gadolinium contrast in T1-weighted images, may provide an early diagnosis of $N F$, demonstrate the need for surgery and determine the extension of involvement, thereby facilitating the surgical procedure. ${ }^{26}$ It is a good technique for revealing the depth of infection and presence of necrosis.

Infections of the soft tissue parts, including cellulitis, myosites and fasciitis, are better evaluated by $C T$ and $M R$ due to excellent anatomic resolution and tissue contrast. ${ }^{27}$

\section{DIAGNOSTIC AND DIFFERENTIAL DIAGNOSIS}

In its early stages, it is difficult to distinguish NF from cellulitis. Several studies indicate that NF frequently begins with cellulitis and blisters. Moreover, NF and hemorrhaging blisters and cellulitis share many other common factors. Both conditions tend to be painful, with a potential to quickly evolve into necrosis and gangrene. They have the same predisposing factors and may have the same etiologic agents (Streptococcus pyogenes). Like NF, the hemocultures in hemorrhaging blisters and cellulitis are positive in more than $60 \%$ of cases. By contrast, they are invariably negative in typical cellulites. ${ }^{7}$

Diagnostic indexes for NF include inelastic edema, cyanosis, paleness and cutaneous hypoesthesia, crepitation, muscular weakness, fetid odor of exudates, absence of lymphangitis, rapid infection progression and lack of response to conventional antibiotherapy.

Systemic manifestations of sepsis are usually present, including changes in mental state, tachycardia, tachypnea, leukocytosis $\left(>12000 \mathrm{~mm}^{3}\right)$, fever $\left(38.9-40.5^{\circ} \mathrm{C}\right)$, 
dia, taquipnéia, leucocitose $\left(>12000 \mathrm{~mm}^{3}\right)$, febre (38.9$40.5^{\circ} \mathrm{C}$ ), acidose metabólica e hipocalcemia. ${ }^{3}$

A aparência relativamente benigna é enganadora e com freqüência resulta em retardo no diagnóstico e aumento da morbimortalidade. O diagnóstico precoce é difícil e incerto.

$\mathrm{Na}$ história clínica, deve-se atentar para os fatores predisponentes, presentes na maioria dos casos (71\%). Relato de trauma prévio pode ocorrer em grande parte dos casos (lesão de pele, $47 \%$ e trauma fechado, $27 \%$ ). ${ }^{2}$

Testes bacteriológicos (diretos e culturas), a partir do exsudato da ferida, fluido da bolha, tecido excisado, material aspirado do subcutâneo e sangue, são essenciais para o diagnóstico apropriado.

Exames radiológicos também são úteis para o estabelecimento do diagnóstico, auxiliando no diagnóstico diferencial, proporcionando intervenção cirúrgica mais precoce e facilitando o plano operatório.

O diagnóstico definitivo é feito à exploração cirúrgica, pela presença de necrose da fáscia.

A reação de cadeia polimerase (PCR) só é utilizada para a detecção de exotoxinas pirogênicas estreptocócicas nos tecidos.

\section{COMPLICAÇÕES}

Aproximadamente a metade dos pacientes com FN apresenta a síndrome do choque tóxico estreptocócico, que é uma condição aguda, fulminante com choque, trombocitopenia, coagulação intravascular disseminada e/ou falência de múltiplos órgãos. ${ }^{2}$ Caracteristicamente, a infecção começa com dor local severa e sintomas não específicos influenza-like. ${ }^{4}$

Alguns autores sugerem que seja usada a denominação síndrome do choque tóxico-like estreptocócico (TSLS), uma vez que a analogia com a síndrome do choque tóxico estafilocócico é inadequada. Esta última é causada pela produção de toxinas, usualmente de uma infecção localizada, não invasiva e não bacterêmica. Já na TS-LS, há em geral uma infecção bacterêmica e invasiva, e não claramente causada por uma toxina pura. Outros fatores de virulência podem estar envolvidos, como a proteína $\mathrm{M}$, polissacarídeos capsulares e outras enzimas extracelulares. ${ }^{4}$

Os achados laboratoriais incluem a diminuição da contagem dos glóbulos brancos, com predominância de granulócitos imaturos. Trombocitopenia, hipocalcemia e hipoalbuminemia também são freqüentemente observados. Pode haver aumento da creatinina sérica e da creatinina-kinase. ${ }^{28}$

É um processo rapidamente progressivo, que mata de 30 a $60 \%$ dos pacientes em prazo que varia de 72 a 96 horas. ${ }^{9}$

Outras complicações potenciais são a insuficiência renal aguda, coagulopatia, alterações hepáticas e síndrome da angústia respiratória do adulto.

\section{FASCIÍTE NECROSANTE EM CRIANÇAS}

A FN é, predominantemente, doença de adultos. Em crianças, é relativamente rara e apresenta curso fulminante com alta taxa de mortalidade. metabolic acidosis and hypocalcemia. ${ }^{3}$

The relatively benign appearance can be misleading and often results in delaying a diagnosis and an increase in morbidity and/or mortality. Early diagnosis is difficult and uncertain.

In the clinical history, one must be attentive to the predisposing factors present in most cases (71\%). Report of previous trauma may occur in most lesions (skin lesions $47 \%$ and closed trauma $27 \%$ ). ${ }^{2}$

Bacteriological tests (direct and cultures) from the wound exudate, blister fluid, excised tissue, aspired material from the subcutaneum and blood, are essential for an appropriate diagnosis.

Radiological exams may also be useful to establishment the diagnosis, aiding in the differential diagnosis, providing earlier surgical intervention and facilitating the surgical procedure.

The definitive diagnosis is effected during surgical exploration, resulting from the presence of necrosis of the fascia.

A polymerase chain reaction (PCR) is only used to detect streptococcal pyrogen exotoxins in the tissue.

\section{COMPLICATIONS}

Approximately half of NF patients show streptococcal toxic shock syndrome. The latter is an acute condition, fulminating with shock, thrombocytopenia, disseminated intravascular coagulation and/or multiple organ failure. ${ }^{2}$ Characteristically, the infection begins with severe local pain and nonspecific influenza-like symptoms. ${ }^{4}$

Some authors suggest that the term streptococcal toxic shock-like syndrome (STSLS) be used since the analogy with staphylococcal toxic shock syndrome is inadequate. The latter is caused by a production of toxins usually from a localized infection, is noninvasive and nonbacteremic. In STSLS, the infection is usually bacteremic and invasive, but not clearly caused by a pure toxin. Other virulent factors may be involved, such as M-protein, capsular polysaccharides and other extracellular enzymes. ${ }^{4}$

Laboratory findings include a reduction in white blood cell count with a predominance of immature granulocytes. Thrombocytopenia, hypocalcemia and hypoalbuminemia are also frequently observed. There may be an increase of seric creatinine and creatinine kinase. ${ }^{28}$

It is a rapidly progressing process, killing 30 to $60 \%$ of patients in the space of 72 to 96 hours. ${ }^{9}$

Other potential complications are acute renal insufficiency, coagulopathy, hepatic alterations and adult respiratory distress syndrome.

\section{NECROTIZING FASCIITIS IN CHILDREN}

$N F$ is predominantly an adult's disease. In children, it is relatively rare and runs a fulminating course with a high mortality rate. 
Em neonatos, a maioria dos casos é atribuída à infecção secundária de onfalites, balanites, mamites, complicações pós-operatórias e monitorização fetal. ${ }^{29}$

$\mathrm{O}$ diagnóstico de FN pode ser considerado na presença de alguma infecção de partes moles com sinais de toxicidade e edema local intenso, mesmo na ausência de febre e alteração na contagem de leucócitos. ${ }^{30} \mathrm{~A}$ aparência de peau d'orange é bastante característica. ${ }^{29,30}$ A flora é polimicrobiana na maioria dos casos, e a coloração pelo gram não tem muita utilidade, podendo ser negativo ou demonstrar apenas um dos vários microorganismos presentes. ${ }^{30}$

Um fator predisponente de FN em crianças bastante citado na literatura é a varicela. Nesses casos, a FN é causada pela infecção secundária das lesões por Streptococcus do grupo A e Staphylococcus. É recomendada intervenção cirúrgica imediata para crianças com varicela que apresentem sintomas que incluem febre, taquicardia e leucocitose em associação com lesão eritematosa, indurada e dolorosa durante dois ou três dias depois do início da infecção viral. Salienta-se que, apesar do risco de uma intervenção cirúrgica desnecessária, a elevada morbimortalidade associada ao retardo do tratamento cirúrgico justifica a exploração precoce. ${ }^{31}$

Cabe ressaltar, ainda, que um recente estudo de caso/controle demonstrou que o uso de ibuprofen aumentou o risco de celulite complicada em crianças com varicela.

\section{TRATAMENTO}

O tratamento bem-sucedido envolve o diagnóstico precoce, debridamento cirúrgico radical de todo o tecido necrótico, antibioticoterapia parenteral de amplo espectro e medidas gerais de suporte agressivas. ${ }^{22}$

As duas falhas mais comuns no manejo desses casos são o retardo no diagnóstico e o debridamento cirúrgico inadequado. A realização de apenas incisão e drenagem, é uma estratégia cirúrgica inadequada para essas infecções. ${ }^{32}$

O debridamento cirúrgico imediato (poucas horas após o início da antibioticoterapia) é imprescindível se o eritema não regredir, com incisões longitudinais estendendo-se até a fáscia profunda e além da área necrótica. Em geral, fazem-se necessários vários debridamentos, e o enxerto de pele é quase sempre necessário. ${ }^{3}$

As medidas gerais de suporte são importantes. A ressuscitação inicial inclui o controle da hipotensão e da disfunção de órgãos decorrentes da sepse severa. Deve-se atentar para a prevenção das complicações associadas ao tratamento intensivo prolongado, incluindo o suporte nutricional e as doenças trombo-embólicas.

A antibioticoterapia isolada não é efetiva, devido ao comprometimento da concentração da droga no local da infecção, prejudicada pela necrose e trombose de vasos sangüíneos.

A penicilina é o antibiótico de escolha para o tratamento das infecções estreptocócicas e possui amplo espectro
In newborns, most cases are attributed to secondary umbilical infection, balanitis, mammytis, post-operative complications and fetal monitoring. ${ }^{29}$

The diagnosis of NF may be considered through the presence of soft tissue infection with signs of toxicity and intense local edema, even with absence of fever and alteration in leukocyte count. ${ }^{30}$ The appearance of peau d'orange is quite characteristic. ${ }^{29,30}$ The flora is polymicrobian in most cases. Gram staining is not very useful as its result might be negative or demonstrate only one of the various microorganisms present. ${ }^{30}$

Chicken pox is often cited in the literature as a predisposing factor for NF in children. In such cases, NF is caused by secondary lesion infection by Group $A$ Streptococcus and Staphylococcus. Surgery is recommended immediately for children with chickenpox showing symptoms offever, tachycardia and leukocytosis in association with an erythematous lesion, induration and pain lasting two or three days after the onset of the viral infection. It should be pointed out that in spite of the risk of unnecessary surgery, the high-level of morbidity and mortality associated with a delay in surgical treatment justifies an early surgical exploration. ${ }^{31}$

It is also appropriate to underscore that the recent case/control study demonstrated that the use of ibuprophen increases the risk of complicated cellulitis in children with chickenpox.

\section{TREATMENT}

Successful treatment involves early diagnosis, radical surgical debridement of the entire necrotic tissue, broad-spectrum parenteral antibiotherapy and general and aggressive patient support measures. ${ }^{22}$

The two most common flaws in the management of these cases are a delay in diagnosis and inadequate surgical debridement. Carrying out only an incision and drainage is an inadequate surgical strategy for these infections. ${ }^{32}$

Immediate surgical debridement (a few hours after beginning antibiotherapy) is indispensable if the erythema does not regress. Longitudinal incisions then have to be extended into the deep fascia and beyond the necrotic area. Various debridements often become necessary, and skin grafting is virtually always necessary. ${ }^{3}$

The general support measures are significant. Initial resuscitation includes control of hypotension and organ dysfunctioning resulting from severe sepsis. One must attend to preventing complications that may occur in association with prolonged, intensive treatment, including nutritional support and thromboembolic diseases.

Isolated antibiotherapy is not effective due to drug concentration involvement at the infection site, aggrieved by the necrosis and venous thrombosis.

Penicillin is the antibiotic of choice for treatment of streptococcal infections and has a broad spectrum of 
de ação: enterobactérias, estreptococos, enterococos e anaeróbios, incluindo Bacteroides spp. No entanto, a clindamicina pode ser teoricamente superior. ${ }^{4}$ Esta última, em experimentos animais, tem demonstrado redução da mortalidade em comparação ao tratamento com penicilina. Um possível mecanismo seria o efeito da clindamicina na síntese protéica, o que poderia diminuir a produção de superantígenos. ${ }^{8}$

Freqüentemente, essas duas drogas são utilizadas em associação para o tratamento das infecções severas por Streptococcus pyogenes. Estudos in vitro sugerem que não há antagonismo no emprego das duas drogas; entretanto, não há nenhum aumento do efeito bactericida com relação ao uso isolado de uma delas.

Um estudo retrospectivo em crianças sugere que a clindamicina, em combinação com beta-lactâmico e cirurgia quando indicada, é o mais efetivo tratamento para infecções invasivas por $S$. pyogenes.

A dose de clindamicina recomendada varia de dois a quatro gramas por dia, iniciada o mais precocemente possível. Quanto à penicilina, recomenda-se utilizar a penicilina $G$ na dose de três a quatro milhões de unidades a cada quatro horas.

Quando se suspeita de infecção mista ou por anaeróbios, acrescenta-se um aminoglicosídeo mais clindamicina ou metronidazol. ${ }^{3}$ Ainda quando há suspeita de flora polimicrobiana, a monoterapia pode ser usada incluindo imipenem/cilastatina ou ticarcilina/clavulanato ou piperacilina/tazobactam.

Em pacientes alérgicos à penicilina e com alto risco de desenvolver nefrotoxicidade com aminoglicosídeos, terapêutica combinada com cefalosporina de terceira geração antipseudomonas, como a ceftazidima, associada ao metronidazol ou clindamicina, pode ser da mesma forma efetiva. ${ }^{13}$

Com base na patogenia, agentes que limitam a produção de citocinas têm sido utilizados com o objetivo de diminuir a destruição tecidual. Eles incluem altas doses de corticóides endovenosos, gamaglobulina e anticorpos contra TNF- $\alpha$ em investigação.

Kerdel enfatiza que a adição de corticóide sistêmico à antibioticoterapia produz rápida melhora, que pode ocorrer no prazo de cinco a sete dias. O autor relata um caso em que utilizou a metilprednisolona endovenosa na dose de $100 \mathrm{mg}$ a cada oito horas, obtendo resultado bastante favorável. ${ }^{8}$

O uso de imunoglobulinas endovenosas tem demonstrado redução significativa de mortalidade na FN e TS-LS., ${ }^{4,35}$ O mais provável mecanismo é a neutralização de superantígenos. ${ }^{8}$ A administração de gamaglobulina é sugerida quando o diagnóstico de TS-LS for seriamente considerado; por exemplo, pacientes hipotensos com celulite de causa desconhecida, pacientes com FN tipo II e pacientes toxêmicos, com cultura de qualquer sítio positiva para estreptococo do grupo A, devem receber gamaglobulina endovenosa. ${ }^{4}$

Outra terapia utilizada é o oxigênio hiperbárico. Existem duas razões para seu uso: o polimorfismo da flora bacteriana com predomínio de anaeróbios e a necrose tissular devida à obstrução microvascular extensa dentro da área infecta- action: enterobacterias, streptococci, enterococci and anaerobics, including Bacteroides supp. Still, the clindamycin may be theoretically superior. ${ }^{4}$ In animal experiments, it has led to a drop in mortality in comparison with the Penicillin treatment. A possible mechanism would be the effect of clindamycin on the proteic synthesis, which may reduce superantigen production. ${ }^{8}$

Frequently, these two drugs are used jointly for treating severe infections for Streptococcus pyogenes. Studies in vitro suggest there to be no antagonism in the use of these two drugs. Nevertheless, there is no increased bacterial effect in relation to using either of them alone.

The retrospective study of children suggests that the clindamycin in combination with beta-lactamic drugs and surgery when indicated is the most effective treatment for invasive infections by $\mathrm{S}$. Pyogenes.

The recommended clindamycin dose varies from two to four grams daily, begun at the earliest possible moment. As for Penicillin, use of Penicillin $G$ is recommended in a dose of three to four million units every four hours.

When one suspects mixed infections or infection by anaerobics, an aminoglycoside is added to clindamycin or metronidazole. ${ }^{3}$ If in addition one suspects polymicrobial flora, monotherapy may be used, including imipenem/cilastatin or ticarcillin/clavulanate or piperacillin/tazobactam.

In patients allergic to Penicillin and at high risk of developing nephrotoxicity with aminoglycosides, therapy combined with third-generation antipseudomonal cephalosporin, with ceftazidime, in association with metronidazole or clindamycin, may be similarly effective. ${ }^{13}$

Pathogeny-based agents that limit cytokine production have been used with the objective of reducing tissue destruction. These include high doses of endovenous corticoids, gammaglobuline and antibodies against the TNFalpha being investigated.

Kerdel emphasizes that adding systemic corticoids to antibiotherapy produces quick improvement, possibly occurring within five to seven days. The author reports a case in which endovenous methylprednisolone was used in a $100 \mathrm{mg}$ dose every eight hours, and obtained very favorable results. ${ }^{8}$

The use of endovenous immunoglobulins has demonstrated a significant reduction of mortality in NF and STSLS. The most probable mechanism is neutralization of superantigens. The administering of gammaglobulin is suggested when the STSLS diagnosis is seriously considered; for example, hypotense patients with cellulitis of an unknown origin, patients with type II NF and toxemic patients with culture from any site testing positive for group A streptococcus, must receive endovenous gammaglobulin. ${ }^{4}$

Another therapy used is hyperbaric oxygen. There are two reasons for its use: polymorphism of bacterial flora with a predominance of anaerobics and tissue necrosis due to extensive microvascular obstruction within the infected area. Clark and Moon believe that studies in vitro and 
da. Clark e Moon acreditam que, apesar de não haver estudos randomizados e controlados que comprovem a eficácia do uso do oxigênio hiperbárico em infecções de partes moles severas, estudos in vitro e metaanálises de casos clínicos suportam o emprego dessa terapêutica. ${ }^{36}$ Mathieu afirma que a associação de oxigenioterapia hiperbárica com antibioticoterapia e cirurgia é baseada em achados fisiopatológicos consistentes, assim como em evidências de estudos animais. $\mathrm{O}$ uso do oxigênio hiperbárico para o tratamento da FN permanece controverso mais pela dificuldade da disponibilidade de equipamento hiperbárico que permita o manejo do paciente em estado crítico do que pelas dúvidas quanto a sua real eficácia.

Atualmente, a amputação só é realizada excepcionalmente, quando o membro acometido já se tornou absolutamente inviável.

\section{PROGNóstico}

O prognóstico da FN depende da idade, das co-morbidades e da severidade da síndrome séptica.

O mais forte preditor de mortalidade associado com FN é a idade. Em pacientes com menos de 35 anos de idade, a taxa de mortalidade é significativamente mais baixa (0\%) quando comparada com a mortalidade em pacientes acima de 70 anos $(65 \%)$. Talvez a instituição de um tratamento menos agressivo nos pacientes idosos possa contribuir para o aumento dos índices de mortalidade. ${ }^{2}$

Outros fatores significativamente associados com aumento do risco de mortalidade são a TS-LS, a hipotensão sem outros comemorativos da TS-LS e a bacteremia. No entanto, esta última só pode ser detectada em prazo que varia de 24 a 48 horas depois da apresentação, não servindo como marcador clínico à admissão. ${ }^{2}$

A mortalidade pode chegar a $100 \%$ nos casos não tratados cirurgicamente e quando há miosite. ${ }^{2,7}$

Algumas modalidades terapêuticas têm sido associadas com melhora do prognóstico. A administração de clindamicina, isoladamente ou em combinação com a penicilina, tem sido associada com diminuição da mortalidade quando comparada com outros antibióticos. ${ }^{2}$

A despeito do conhecimento e dos avanços no tratamento, a FN permanece com taxas de mortalidade que variam de 35 a 40\%. Antes de 1980, pacientes jovens e saudáveis com envolvimento isolado de uma extremidade apresentavam mortalidade menor do que $5 \%$, enquanto naqueles com mais de 50 anos ou com envolvimento de tronco ou períneo, a mortalidade chegava a ser maior do que $60 \%$. A mortalidade é também alta em pacientes com doenças crônicas, como diabetes mellitus ou doenças cardiovasculares. Desde 1990, a taxa de mortalidade global tem sido em torno de $30 \%$.

O diagnóstico precoce e a intervenção cirúrgica rápida e agressiva são a chave para a redução da morbidade e mortalidade. ${ }^{1,3}$ Nos casos diagnosticados e tratados nos quatro dias imediatamente posteriores ao início dos sintomas, a taxa de mortalidade cai para $12 \% .^{3}$ meta-analyses of clinical cases support the use of this therapy in spite of there not being randomized and controlled studies proving the effectiveness of the hyperbaric oxygen used in severe infections of the soft tissues. ${ }^{36}$ Mathieu asserts that the association with hyperbaric oxygenotherapy with antibiotherapy and surgery is based on consistent physiological findings, such as the ones found in animal studies. The use of hyperbaric oxygen for treating NF remains controversial owing more to the difficulty of making hyperbaric equipment available, and thereby allowing a patient in critical state to be managed, than from any doubts related to its real effectiveness.

At the present time, amputation is only performed exceptionally, namely when the afflicted limb has already become absolutely unviable.

\section{PROGNOSIS}

The prognosis of NF depends on age, co-morbidities and severity of the septic syndrome.

The strongest predictor of mortality associated with $N F$ is age. For patients under the age of 35, the mortality rate is significantly lower (0\%) than when compared to mortality in patients over 70 years of age (65\%). It is possible that instituting less aggressive treatment in elderly patients may have contributed to increasing the mortality indexes. $^{2}$

Other significantly associated factors with increased risk of mortality are STSLS, hypotension with no other STSLS remnants and bacteremia. However, the latter may only be detected in a period varying from 24 to 48 hours after first appearing, which is of little use as an acceptable clinical marker. $^{2}$

Mortality may reach $100 \%$ of surgically non-treated cases and when there is myositis. ${ }^{2,7}$

A few therapeutic modalities have been associated with improving the prognosis. Administering clindamycin, alone or in combination with Penicillin, has been associated with a drop in mortality when compared to other antibiotics. $^{2}$

Despite better know-how and advances in treatment, NF continues to have mortality rates varying from 35 to $40 \%$. Prior to 1980, young and healthy patients with isolated involvement of an extremity showed lower than $5 \%$ mortality, while in those over 50 years of age or with trunk or perineal involvement mortality exceeded $60 \%$. Mortality is also high in patients with chronic diseases, like diabetes mellitus or cardiovascular diseases. Since 1990, the global mortality rate has been roughly $30 \%{ }^{1,3}$

Early diagnosis, and rapid and aggressive surgical intervention are capital to reducing morbidity and mortality. In cases diagnosed and treated within four days immediately after the onset of symptoms, the mortality rate drops to $12 \% .^{3}$ 


\section{DISCUSSÃO}

Lille e col. recomendam a solicitação de parecer cirúrgico, considerando a exploração precoce, tão logo o diagnóstico de FN seja suspeitado. O retardo na intervenção cirúrgica pode trazer consequiências adversas, tanto médicas quanto legais. ${ }^{37}$

O tratamento deve ser iniciado o mais cedo possível, já que o atraso de poucas horas pode ser crítico. ${ }^{4}$

Portanto, para que seja alcançado o objetivo de redução dos altos índices de morbimortalidade dessa infecção, faz-se necessária a observação de vários fatores. Deve ser dada atenção especial aos casos de celulite, considerando-os todos passíveis de cirurgia, principalmente as bolho-hemorrágicas e em pacientes com qualquer um dos fatores de risco para FN, seja pela observação mais rigorosa da resposta inicial à antibioticoterapia convencionalmente instituída ou evitando a alta hospitalar precoce. É preciso atentar para os casos nos quais, embora tenha havido aparente melhora dos sinais flogísticos locais, o paciente continua queixando-se de dor intensa. Como já referido, tão logo tal diagnóstico seja aventado, o parecer cirúrgico deve ser solicitado. O risco de uma intervenção cirúrgica desnecessária é suplantado pelas potenciais complicações clínicas e legais. A antibioticoterapia deve ser instituída o mais rapidamente possível, lembrando que, em ordem de importância, o debridamento cirúrgico está em primeiro lugar, utilizando-se preferencialmente a clindamicina, que em vários trabalhos tem-se mostrado superior à penicilina. Quando se suspeita de flora mista, o espectro deve ser aumentado para a cobertura de anaeróbios, associando-se cefalosporinas de terceira geração e metronidazol ou outras drogas, como o imipenem em monoterapia. Quando se instalam complicações como o choque, o paciente deve ser tratado, preferencialmente, em unidade de terapia intensiva com monitorização cardíaca, controle hidroeletrolítico adequado (reposição de fluidos), além de suporte nutricional e respiratório, caso necessário.

\section{CONCLUSÃO}

FN é infecção bacteriana destrutiva e rapidamente progressiva do tecido subcutâneo e fáscia superficial, associada a altos índices de morbimortalidade se não tratada precocemente. Portanto, o dermatologista deve estar atento para a existência dessa patologia, cujo principal diagnóstico diferencial é a celulite. Desse modo, na presença de quadro clínico compatível com celulite com resposta parcial à antibioticoterapia, especialmente se acompanhado de dor e bolhas hemorrágicas, deve-se pensar no diagnóstico de FN, permitindo a abordagem terapêutica precoce e diminuindo seus elevados índices de morbimortalidade.

\section{DISCUSSION}

Lille and col. recommend soliciting a surgeon's opinion in order to consider an early surgical exploration as soon as the diagnosis of NF is suspected. A delay in surgical intervention may bring on adverse consequences, either medical or legal. ${ }^{37}$

Treatment must be initiated at the earliest possible moment given that a few hours delay may be critical. ${ }^{4}$

Yet to reach the objective of reducing the infection's high morbidity and mortality indexes, it is necessary to observe various factors. What must be given utmost attention are cases of cellulitis. All such cases may be subject to surgery, especially blister and hemorrhagic cellulites. And this applies to patients with any one of the NF risk factors, whether by the most rigorous observation of the initial response to conventionally instituted antibiotherapy or by avoiding early release from hospital.

Even though some cases may show apparent improvement of It is necessary to attend to cases though they show apparent improvement of local signs and symptoms, the patient kept complaining of intense pain. As mentioned previously, once the diagnosis is reached, a surgeon's opinion must be solicited. Risk of an unnecessary surgical operation is supplanted by potential clinical and legal complications. Antibiotherapy must be implemented as soon as possible, bearing in mind the following items in order of importance: surgical debridement is first, with a preference for clindamycin use, which various papers have shown to be superior to Penicillin. When a mixed flora is suspected, the spectrum must be increased to include anaerobics in association with third-generation cephalosporin and metronidazole or other drugs like imipenem monotherapy. When complications such as shock set in, the patient must be treated preferentially in an intensive therapy unit with cardiac monitoring and adequate hydroelectrolytic control (fluid replacement), in addition to nutritional and respiratory support if and when necessary.

\section{CONCLUSION}

$N F$ is a destructive bacterial infection of the subcutaneous tissue and superficial fascia which progresses rapidly. It is associated with high indexes of morbidity and mortality if not treated early. Hence the dermatologist must be attentive to the existence of this pathology, whose main diagnostic differential is cellulitis. Therefore, in the presence of a clinical condition compatible with cellulitis with partial response to antibiotherapy, especially if accompanied by pain and hemorrhagic blisters, a diagnosis of NF must be considered. This should allow an early therapeutic approach that can reduce its high morbidity and mortality indexes. 


\section{REFERÊNCIAS / REFERENCES}

1. Fink S, Chaudhuri TK, Davis HH. Necrotizing fasciitis and malpractice claims. South Med J 1999; 92(8):770-4.

2. Kaul R et al. Population-based surveillance for group A streptococcal necrotizing fasciitis: clinical features, prognostic indicators, and microbiologic analysis of seventy-seven cases. Am J Med 1997; 103:18-24.

3. Morantes MC, Lipsky BA. "Flesh-eating bacteria": return of an old nemesis. Internacional Journal of Dermatology 1995; 34(7)461-63.

4. Feingold DS, Weinberg AN. Group A streptococcal infections. An old adversary reemerging with new tricks?. Arch Dermatol 1996; 132:67-70.

5. Baskin LS, Carol PR, Catholic EVE et al. Necrotizing soft tissue infections of the perineum and genitalia: bacteriology, treatment, and risk assessment. Br J Urol 1990; 65:524-29.

6. Martin PR, Hoiby EA. Streptococcal serogroup A epidemic in Norway 1987-1988. Scand J Infect Dis 1990; 22:421-29.

7. Gardam MA, Low DE, Saginur R, Miller MA. Group B streptococcal necrotizing fasciitis and streptococcal toxic shock-like syndrome in adults. Arch Intern Med 1998; 158(15):1704-8.

8 . Kerdel F. Necrotizing fasciitis: early recognition reduces morbidity/mortality. Dermatology Times 1998; 6-9.

9. Norrby SR, Norrby-Teglund A. Infections due to group A streptococcus: new concepts and potencial treatment strategies. Ann Acad Med Singapore 1997; 26(5):691-3.

10. Stevens DL. Streptococcal toxic schock syndrome associated with necrotizing fasciitis. Annu Rev Med 2000; 51:271-88.

11. Meltzer-DL, Kabongo-M. Necrotizing fasciitis: a diagnostic challenge. Am Fam Physician 1997; 56(1):145-9.

12. Jarret P, Rademaker M, Duffill M. The clinical spectrum of necrotizing fasciitis. A review of 15 cases. Aust N Z J Med 1997; 27(1):29-34.

13. Marcus JR, Hussong WJ, Gonzales C, Dumaniam GA. Risck factors in necrotizing fasciitis: a case involving Cryptococcus neoformans. Ann Plast Surg 1998; 40(1):80-3.

14. Hill MK, Sanders CV. Infections in critical care II. Critical Care Clinics 1998; 14(2):251-62.

15. Gonzales MH. Necrotizing fasciitis and gangrene of the upper extremity. Hand Clin 1998; 14(4):635-45.

16. Bilton BD et al. Agressive surgical management of necrotizing fasciitis serves to decrease mortality: a retrospective study. Am Surg 1998; 64(5):397-400.

17. Smith RJ, Berk SL. Necrotizing fasciitis and non-steroidal anti-inflamatory drugs. South Med J 1991; 86:785-87.

18. Holder EP, Moore PT, Browne BA. Nonsteroidal anti-inflammatory drugs and necrotizing fasciitis. An update. Drugs Saf 1997; 17(6):369-73.

19. Guibal F, Muffat-Joly M, Terris B, Garry L, Morel P, Carbon C. Effects of diclofenac on experimental streptococcal necrotizing fasciitis in rabbit. Arch Dermatol Res 1998; 290(11):628-33.

20. Stevens DL, Tanner MH, Winship I et al. Severe group A streptococcal infections associated with a toxic shock-like syndrome and scarlet fever toxin. NEJM 1989; 321:1-7.

21. Forni al, Kaplan EL, Shlievert PM, Roberts RB. Clinical and microbiological characteristics of severe group A streptococcal infections and streptococcal toxic shock syndrome. Clin Infect Dis $1995 ; 21: 333-40$.
22. Chelsom I, J Halstensen A, Haga T, Hoiby EA. Necrotizing fasciitis due to group A streptococci in Western Norway: incidence and clinical features. Lancet 1994; 344:1111-1115.

23. Majeski J, Majeski E. Necrotizing fasciitis: improved survival with early recognition by tissue biopsy and aggressive surgical treatment. South Med J 1997; 90(11):1065-8.

24. Ciccone G, Bonvicini R, Zanola S, Bombonato M, Ceraminiello A. Necrotizing fasciitis. A diagnostic and therapeutic challenge. Minerva Chir 1999; 54(11):819-23.

25. Walshaw CF, Deans H. CT findings in necrotizing fasciitis- a report of four cases. Clin Radiol 1996; 51:429-32.

26. Brothers TE and col. Magnetic resonance: imaging differentiates between necrotizing and non-necrotizing fasciitis of the low extremity. J Am Coll Surg 1998; 187(4):416-21.

27. Ma LD, Frassica FJ, Bluemke DA, Fishman EK. CT and MRI evaluation of musculoskeletal infection. Crit Ver Diagn Imaging 1997; 38(6):535-68.

28. Michael EP. Group A beta-hemolytic streptococcal infections. Pediatrics in Review 1998; 19(9):291-32.

29. Hsiech WS, Yang PH, Chao HC, Lai JY. Neonatal necrotizing fsciitis: a report of three cases and review of the literature. Pediatrics 1999; 103(4): e53.

30. Moss RL, Musemeche CA, Koloske AM. Necrotizing fasciitis in children: prompt recognition and aggressive therapy improve survival. J Pediatr Surg 1996; 31(8):1142-6.

31. Waldhausen JH, Holterman MJ, Sawin RS. Surgical implications of necrotizing fasciitis in children with chickenpox. J Pediatr Surg 1996; 31(8):1138-41.

32. Urschel JD. Necrotizing soft tissue infections. Postgrad Med J 1999; 75(889):645-9.

33. Stevens DL, Madaras-Kelly KJ, Richards DM. In vitro antimicrobial effects of various combinations of penicillin and clindamycin against four strains of Streptococcus pyogenes. Antimicrob Agents Chemother 1998; 42(5):1266-8.

34. Zimbelman J, Palmer A, Todd J. Improved outcome of clindamycin compared with beta-lactam antibiotic treatment for invasive Streptococcus pyogenes infection. Pediatr Infect Dis J 1999; 18(12):1096-100.

35. Cawley MJ, Briggs M, Haith LR Jr, Reilly KJ, Guilday RE, Braxton GR, Patton ML. Intravenous imunoglobulin as adjunctive treatment for streptococcal toxic shock syndrome associated with necrotizing fasciitis: case report and review. Pharmacotherapy 1999; 19(9):1094-8.

36. Clark LA, Moon RE. Hiperbaric oxygen in the treatment of life-threatening soft-tissue infections. Respir Care Clin N Am 1999; 5(2):203-19.

37. Lille ST, Sato TT, Engrav LH et al: Necrotizing soft tissue infections: obstacles in diagnosis. J Am Coll Surg 1996; 182:7-11.

\footnotetext{
ENDEREÇO PARA CORRESPONDÊNCIA: / MAILING ADDRESS:

Izelda Maria Carvalbo Costa

SHIS QI 17 Conjunto 08 Casa 02

71645-080 Brasília DF

Tel.: (61) 364-1702

E-mail:izelda@brturbo.com.br
} 